\title{
Effect of residue mixtures on response of cumulative respiration to salinity
}

\author{
H. Hasbullah*, P. Marschner
}

School of Agriculture, Food and Wine, The University of Adelaide, Adelaide SA 5005, Australia. *Corresponding author: hasz.hasbullah@gmail.com

\begin{abstract}
The study aimed to investigate the response of soil respiration to salinity when amended with mixtures of rapidly and slowly decomposable residues. Two incubation experiments were carried out with loam soils having $\mathrm{EC}_{1: 5} 0.1,1.0,2.5$ and $3.3 \mathrm{dS} \mathrm{m}^{-1}$. In experiment one, the four soils were amended with $20 \mathrm{~g} \mathrm{~kg}^{-1}$ soil as sawdust $(\mathrm{C} / \mathrm{N} 114)$ or kikuyu $(\mathrm{C} / \mathrm{N} 19)$ alone or mixed at different ratios. In all mixtures, the decrease in cumulative respiration at $1 \mathrm{dS} \mathrm{m}^{-1}$ compared to non-saline soil was smaller than with sawdust alone. In experiment two, three soils $\left(\mathrm{EC}_{1: 5} 0.1,1.0\right.$ and $\left.2.5 \mathrm{dS} \mathrm{m}^{-1}\right)$ were amended once or three times to a total addition rate of $10 \mathrm{~g} \mathrm{C} \mathrm{kg}^{-1}$ soil either with sawdust alone, kikuyu alone or mixtures. In the treatments with mixtures, the decrease in cumulative respiration from non-saline to $\mathrm{EC} 1 \mathrm{dS} \mathrm{m}^{-1}$ was smallest in the treatments with three residue additions where $25 \%$ kikuyu was added on day 0 or on day 14 after addition of $50 \%$ sawdust on day 0 . We conclude that even a relatively small proportion of rapidly decomposable residue in a mixture is sufficient to alleviate the negative impact of salinity on soil respiration.
\end{abstract}

Keywords: Residue mixes, respiration, salinity

\section{Introduction}

Salinity is one of the major factors limiting agricultural production in many arid and semi-arid areas, including 357 Mioha land in Australasia (Pessarakli and Szabolcs, 1999). In Australia, the salt affected area is predicted to increase by another 15 Mioha in the next 50 years due to human activities such as poor irrigation and drainage systems, the expansion of irrigation into arid zones and clearing of native vegetation (Lambers, 2003).
Salinity has been shown to reduce microbial biomass, activity and change community structure (Rietz and Haynes, 2003). The adverse effect of salinity on soil microbes can be explained by the low osmotic potential which makes it difficult to take up or retain water, and nutrient imbalance because of ion competition (Marschner, 2012). Sensitive microbes die, but some microbes accumulate organic or inorganic osmolytes thereby minimising water loss from the cells (Hagemann, 2011). 
Synthesis of organic osmolytes requires a significant amount of energy (Oren, 1999).

Organic matter decomposition is the main energy source for most soil microbes, but organic matter content in saline soils is often low due to poor plant growth (Setia et al., 2011b). Addition of organic matter has been shown to increase microbial activity in saline soils (Yan and Marschner, 2012) and could reduce the negative impact of salinity on microbes by providing energy for osmolyte synthesis. In most studies a single type of organic amendment is used. We recently showed that the negative impact of salinity on respiration was greater in soil amended with slowly decomposable residues compared to rapidly decomposable residues (Hasbullah and Marschner, 2014).

In the field, slowly decomposable residues (e.g. sawdust or mature cereal straw) are often available in greater quantities and at lower cost than rapidly decomposable residues (e.g. young grass or legume shoots). Amelioration of saline soils with residue mixtures of slowly and rapidly decomposable residues may therefore be a cost-effective option. However, it is not clear what proportion of easily decomposable residue is required to achieve a similar ameliorative effect as with easily decomposable residue alone.

A consistent supply of organic $\mathrm{C}$ could be more effective in alleviating the negative effect of salinity on microbial activity than a single addition where decomposable compounds are depleted soon after application. With repeated addition, residue type, amount and timing could vary among applications. It is not clear if in soil amended with residue mixtures, proportion or timing of amendment with rapidly decomposable residue influence the impact of salinity on soil respiration and microbial biomass.

Two experiments were conducted with sawdust as slowly decomposable residue and young kikuyu shoots as rapidly decomposable residue. The aim of the first experiment was to investigate the influence of salinity on soil respiration with a single addition of slowly or rapidly decomposable residues alone or as mixture with different proportions of the two residues. The aim of the second experiment with multiple residue additions was to determine the influence of the proportion of slowly decomposable residue in the soil at the time of addition of rapidly decomposable residue on response of soil respiration to increasing salinity. We hypothesised that (i) with a single addition, the negative effect of salinity on soil respiration will decrease with increasing proportion of rapidly decomposable residue in the mixture, and (ii) with multiple residue additions, the negative impact of salinity on cumulative respiration will increase with proportion of slowly decomposable residue in the soil at the time of addition of rapidly decomposable residue. The second hypothesis is based on the assumption that the likelihood of microbes being in the vicinity of freshly added rapidly decomposable residue will decrease as the proportion of slowly decomposable residue already present in the soil is high.

\section{Materials and Methods}

\subsection{Soils}

Four loam soils were collected from the A horizon (0$30 \mathrm{~cm}$ depth) in areas with patches of salinity in Monarto, South Australia $\left(35^{\circ} 05^{\prime} \mathrm{S}\right.$ and $139^{\circ} 06^{\prime} \mathrm{E}$ ) (Table 1). These soils are wide-spread in the region. This area has a Mediterranean climate with hot dry summer (long term average: $29.4^{\circ} \mathrm{C}$ ) and cool wet winter (long term average: $14.7^{\circ} \mathrm{C}$ ) (Meat and Livestock Australia, 2015). The soils were air-dried, sieved to $2 \mathrm{~mm}$ and then stored. Salinity determined as electrical conductivity in a 1:5 (soil: water, $\mathrm{w} / \mathrm{w}$ ) extract ( $\mathrm{EC}_{1: 5}$ ) was 0.1 (non-saline), 1.0, 2.5 and $3.3 \mathrm{dS} \mathrm{m}^{-1}$. This range was chosen based on a previous study to 
induce a moderate to strong decrease in respiration (unpublished data). The saline soils were salinesodic (Sodium Adsorption Ratio $<6$ for Australian soils) and therefore do not display dispersive behav- iour associated with sodicity because the high salt concentration in the soil solution causes flocculation of soil particles (Sumner and Naidu, 1998)

Table 1. Physical and chemical properties of non-saline and three saline soils (from Hasbullah and Marschner 2014)

\begin{tabular}{|c|c|c|c|c|}
\hline \multirow[t]{2}{*}{ Parameter $^{1}$} & \multicolumn{4}{|c|}{$E C_{1: 5}\left(d^{2} ~ m^{-1}\right)$} \\
\hline & 0.1 & 1.0 & 2.5 & 3.3 \\
\hline $\mathrm{EC}_{\mathrm{e}}\left(\mathrm{dS} \mathrm{m} \mathrm{m}^{-1}\right)$ & $2.5 \pm 0.02$ & $13.9 \pm 0.45$ & $34.7 \pm 1.67$ & $44.5 \pm 1.08$ \\
\hline Sand $(\%)$ & 50 & 45 & 47.5 & 47.5 \\
\hline Silt $(\%)$ & 35 & 35 & 32.5 & 32.5 \\
\hline Clay $(\%)$ & 15 & 20 & 20 & 20 \\
\hline Texture & Loam & Loam & Loam & Loam \\
\hline Water holding capacity $(\%)$ & 32 & 37 & 39 & 44 \\
\hline $\mathrm{pH}$ & $7.8 \pm 0.10$ & $9.0 \pm 0.06$ & $8.7 \pm 0.06$ & $9.0 \pm 0.04$ \\
\hline Total organic carbon $(\%)$ & $1.2 \pm 0.04$ & $1.1 \pm 0.02$ & $0.9 \pm 0.03$ & $0.7 \pm 0.03$ \\
\hline \multicolumn{5}{|l|}{ Total elements } \\
\hline $\mathrm{N}\left(\mathrm{g} \mathrm{kg}^{-1}\right)$ & $1.48 \pm 0.20$ & $0.95 \pm 0.04$ & $0.95 \pm 0.08$ & $0.88 \pm 0.08$ \\
\hline $\mathrm{P}\left(\mathrm{mg} \mathrm{kg}^{-1}\right)$ & $848 \pm 73.72$ & $423 \pm 7.49$ & $318 \pm 19.12$ & $279 \pm 6.51$ \\
\hline $\mathrm{K}\left(\mathrm{g} \mathrm{kg}^{-1}\right)$ & $5.7 \pm 0.57$ & $6.1 \pm 0.21$ & $6.5 \pm 0.30$ & $7.0 \pm 0.13$ \\
\hline $\mathrm{Al}\left(\mathrm{g} \mathrm{kg}^{-1}\right)$ & $32.4 \pm 1.50$ & $39.6 \pm 0.03$ & $40.0 \pm 1.18$ & $38.3 \pm 0.66$ \\
\hline $\mathrm{Fe}\left(\mathrm{g} \mathrm{kg}^{-1}\right)$ & $25.9 \pm 1.70$ & $31.7 \pm 0.23$ & $33.0 \pm 0.60$ & $30.7 \pm 1.49$ \\
\hline \multicolumn{5}{|l|}{ Available nutrients } \\
\hline $\mathrm{NH}_{4} \mathrm{~N}\left(\mathrm{mg} \mathrm{kg}^{-1}\right)$ & $40.1 \pm 0.97$ & $43.7 \pm 0.84$ & $41.4 \pm 0.91$ & $46.7 \pm 0.32$ \\
\hline $\mathrm{NO}_{3} \mathrm{~N}\left(\mathrm{mg} \mathrm{kg}^{-1}\right)$ & $8.5 \pm 0.09$ & $8.7 \pm 0.09$ & $2.7 \pm 0.09$ & $1.3 \pm 0.05$ \\
\hline Colwell P ( $\left.\mathrm{mg} \mathrm{kg}^{-1}\right)$ & $70 \pm 1.13$ & $24 \pm 0.66$ & $25 \pm 0.76$ & $17 \pm 0.19$ \\
\hline \multicolumn{5}{|l|}{$\begin{array}{l}\text { Soluble cations ( } 1: 5 \text { soil: } \\
\text { water extract) }\end{array}$} \\
\hline $\mathrm{Ca}\left(\mathrm{mmol} \mathrm{L}^{-1}\right)$ & $0.51 \pm 0.00$ & $0.49 \pm 0.02$ & $0.96 \pm 0.03$ & $0.44 \pm 0.04$ \\
\hline $\mathrm{Na}\left(\mathrm{mmol} \mathrm{L}^{-1}\right)$ & $0.22 \pm 0.00$ & $9.79 \pm 0.31$ & $21.31 \pm 0.62$ & $30.01 \pm 0.00$ \\
\hline $\mathrm{Mg}\left(\mathrm{mmol} \mathrm{L}^{-1}\right)$ & $0.22 \pm 0.00$ & $0.29 \pm 0.02$ & $0.93 \pm 0.03$ & $1.01 \pm 0.01$ \\
\hline SAR $_{1: 5}$ & 0.3 & 11.1 & 15.5 & 24.9 \\
\hline
\end{tabular}

${ }^{1} \mathrm{n}=3 \pm$ standard deviation except for texture, water holding capacity and SAR where $\mathrm{n}=1$.

\subsection{Plant residues}

Two residues with distinct properties were used in both experiments: shoots of kikuyu (Pennisetum clandestinum $\mathrm{L}$.) with low $\mathrm{C} / \mathrm{N}$ ratio and lignin concentration and sawdust [from pine wood (Pinus sp.)] with high $\mathrm{C} / \mathrm{N}$ ratio and lignin concentration (Table 2). Both residues were ground and sieved to particle size $0.25-2 \mathrm{~mm}$. These residues were chosen because in our previous study, where we used the same saline soils (Hasbullah and Marschner, 2014), the decrease in respiration with increasing salinity was greater in soils amended sawdust than in kikuyu-amended soils. 
Table 2. Selected properties of sawdust and kikuyu shoots. $n=3 \pm$ standard deviation for organic $\mathrm{C}$, total N, waterextractable organic $\mathrm{C}$ and Klason lignin.

\begin{tabular}{lll}
\hline Plant residues & Sawdust & $\begin{array}{l}\text { Kikuyu } \\
\text { shoots }\end{array}$ \\
\hline Organic C $\left(\mathrm{g} \mathrm{kg}^{-1}\right)$ & $437 \pm 42.9$ & $341 \pm 40.2$ \\
Total N $\left(\mathrm{g} \mathrm{kg}^{-1}\right)$ & $3.8 \pm 0.31$ & $17.6 \pm 0.64$ \\
C/N ratio & 114 & 19 \\
$\begin{array}{l}\text { Water extractable organic C } \\
\left(\mathrm{g} \mathrm{kg}^{-1}\right)\end{array}$ & $8.4 \pm 0.24$ & $2.1 \pm 0.02$ \\
Carbohydrate $(\%)$ & 51 \\
Carbonyl $(\%)^{2}$ & 50 & 2 \\
Lipid $(\%)^{2}$ & 5 & 4 \\
Protein $(\%)^{2}$ & 20 & 19 \\
Lignin $(\%)^{2}$ & 3 & 15 \\
Klason lignin $(\%)$ & 22 & $37 \pm 1$ \\
\hline
\end{tabular}

${ }^{1}$ Concentrations calculated from ${ }^{13} \mathrm{C}$ NMR results using a molecular mixing model [34]. Values do not necessarily add up to $100 \%$ as some $\mathrm{C}$ species (e.g. ketones) are excluded from the model.

\subsection{Experimental design}

The study included of two experiments, where the second experiment was based on the results of the first. Before the start of the experiments, the soils were wet to $55 \%$ of maximum water holding capacity and incubated for 14 days to stabilise respiration after the initial flush of respiration upon rewetting of air-dry soil. In our previous studies soil respiration in these soils was maximal at this water content.
The objective of Experiment 1 was to investigate the influence of salinity on respiration in soil amended with slowly or rapidly decomposable residues alone or as mixture. After pre-incubation, residues were added into thenon-saline soil $\left(\mathrm{EC}_{1: 5} 0.1 \mathrm{dS} \mathrm{m}^{-1}\right)$ and the three saline soils (EC 1, 2.5 and $3.3 \mathrm{dS} \mathrm{m}^{-1}$ ) at a rate of $20 \mathrm{~g} \mathrm{~kg}^{-1}$ either as individual residues: sawdust alone (S100/K0) or kikuyu alone (S0/K100) or as mixtures. For the mixture treatments, the residues were thoroughly mixed before addition to the soils. 
The following mixtures were prepared where the first number is the weight percentage of sawdust and the second that of kikuyu: S75/K25, S50/K50 and $\mathrm{S} 25 / \mathrm{K} 75$. Soil with residues (equivalent to $20 \mathrm{~g}$ moist soil) was filled into PVC cores with $1.85 \mathrm{~cm}$ radius, $5 \mathrm{~cm}$ height and a nylon mesh base $(0.75 \mu \mathrm{m}$, Australian Filter Specialist) and packed to a bulk density of $1.4 \mathrm{~g} \mathrm{~cm}^{-3}$. The cores were placed individually into $1 \mathrm{~L}$ glass jars with gas tight lids equipped with septa to allow quantification of the headspace $\mathrm{CO}_{2}$ concentration (see below). Soil respiration was measured over 16 days.

The aim of Experiment 2 was to determine the effect of residue addition frequency and order in which residues are added on response of soil respiration to salinity. The two residue were added into thenon-saline soil $\left(\mathrm{EC}_{1: 5} 0.1 \mathrm{dS} \mathrm{m}^{-1}\right)$ and two saline soils (EC 1 and $2.5 \mathrm{dS} \mathrm{m}^{-1}$ ) to achieve a total addition of $10 \mathrm{~g} \mathrm{C} \mathrm{kg}^{-1}$. This rate corresponds to approximately $20 \mathrm{~g}$ residue $\mathrm{kg}^{-1}$ which is the rate used in Experiment 1. In Experiment $1,25 \%$ kikuyu in the mixture was sufficient to alleviate the negative effect of salinity on soil respiration. Therefore, the mixed treatments in Experiment 2 consisted of $75 \%$ sawdust $+25 \%$ kikuyu. The residues were added once, twice or three times. For the single additions, residues were added on day zero. For the multiple additions, the residues were added every two weeks: on days 0, 14 and 28 (see Table 3 for details). When mixtures were applied, the residues were mixed before addition to the soil. The mixed treatments were designed so that $25 \%$ kikuyu was added either on day 0 , day 14 or day 28 . In treatments where residues were applied only on day $0(10 \mathrm{~S}, 10 \mathrm{~K}, 7.5 \mathrm{~S}+2.5 \mathrm{~K}$ where the value indicates the $\mathrm{C}$ rate, $\mathrm{S}$ and $\mathrm{K}$ stand for sawdust and kikuyu), the soil was mixed on days 14 and 28 in a similar manner as in those treatments with residue addition on these dates. Preparation of cores was as described for Experiment 1. Soil respiration was measured for 42 days and microbial biomass $C$ was measured at the end of experiment.

In both experiments, the glass jars with soil samples were kept at room temperature $\left(19-23{ }^{\circ} \mathrm{C}\right)$ in the dark. Soil moisture was maintained at $55 \%$ of maximum water holding capacity (WHC) by checking the water content every few days by weight and adding RO water if necessary.

Table 3. Organic C addition treatments in Experiment 2.

\begin{tabular}{lccc}
\hline Treatment & \multicolumn{3}{c}{ Day } \\
\cline { 2 - 4 } & 0 & C addition rate $(\mathrm{g} \mathrm{C} / \mathrm{kg})$ & 28 \\
\hline $10 \mathrm{~S}$ & $10 \mathrm{~S}$ & 0 & 0 \\
$10 \mathrm{~K}$ & $10 \mathrm{~K}$ & 0 & 0 \\
$7.5 \mathrm{C}+25 \mathrm{~K}$ & $7.5 \mathrm{~S}+2.5 \mathrm{~K}$ & 0 & 0 \\
$5 \mathrm{~S}-2.5 \mathrm{~S}-2.5 \mathrm{~S}$ & $5 \mathrm{~S}$ & $2.5 \mathrm{~S}$ & $2.5 \mathrm{~S}$ \\
$5 \mathrm{~S}-2.5 \mathrm{~K}-2.5 \mathrm{~S}$ & $5 \mathrm{~S}$ & $2.5 \mathrm{~K}$ & $2.5 \mathrm{~S}$ \\
$5 \mathrm{~S}-2.5 \mathrm{~S}-2.5 \mathrm{~K}$ & $5 \mathrm{~S}$ & $2.5 \mathrm{~S}$ & $2.5 \mathrm{~K}$ \\
$(2.5 \mathrm{~S}+2.5 \mathrm{~K})-2.5 \mathrm{~S}-2.5 \mathrm{~S}$ & $2.5 \mathrm{~S}+2.5 \mathrm{~K}$ & $2.5 \mathrm{~S}$ & $2.5 \mathrm{~S}$ \\
$5 \mathrm{~K}-2.5 \mathrm{~K}-2.5 \mathrm{~K}$ & $5 \mathrm{~K}$ & $2.5 \mathrm{~K}$ & $2.5 \mathrm{~K}$ \\
\hline
\end{tabular}




\subsection{Soil and residue analyses}

Soil EC and $\mathrm{pH}$ were measured in a 1:5 soil to reverse osmosis (RO) water suspension after one hour horizontal shaking at $25^{\circ} \mathrm{C}$. The formula from Shaw et al. (1987) was used to calculate EC in the saturated paste extract $\left(\mathrm{EC}_{\mathrm{e}}\right)$ from $\mathrm{EC}_{1.5}: \mathrm{EC}_{\mathrm{e}}=\mathrm{EC} 1: 5(-2.21 \times \%$ Clay $\left.{ }^{0.5}+23.78\right)$.

Soil texture was determined by the hydrometer method (Ashworth et al., 2001), texture classification was based on Saxton et al. (1986). Maximum water holding capacity (WHC) of the soils was measured by using a sintered glass funnel connected to a $1 \mathrm{~m}$ water column ( $\left.\Psi_{\mathrm{m}}=-10 \mathrm{kPa}\right)$ (Haines, 1930). The soils were placed in cores in a sintered glass funnel, thoroughly wetted and allowed to drain for two days. The drained soil was weighed before and after oven drying at 105 ${ }^{\circ} \mathrm{C}$ for 24 hours to determine the water content. For total $\mathrm{P}, \mathrm{Al}, \mathrm{Fe}$ and $\mathrm{K}$, the soils were digested with hydrochloric acid as described in Zarcinas et al. (1996). Available P was extracted using the Colwell method and measured colorimetrically at $882 \mathrm{~nm}$ (Rayment and Higginson, 1992). Soil inorganic N was extracted in $1 \mathrm{M} \mathrm{KCl}$; ammonium and nitrate concentrations were determined using standard colorimetric methods (Keeney and Nelson, 1982). Soluble $\mathrm{Na}^{+}, \mathrm{Ca}^{2+}$ and $\mathrm{Mg}^{2+}$ concentrations were extracted by 1 hour horizontal shaking of a suspension with 1:5 soil: water ratio and filtering through Whatman filter No. 42. Element concentrations in the extracts were measured by ICP-AES (Inductively Coupled Plasma Atomic Emission Spectrometry).Sodium adsorption ratio (SAR) was calculated from soluble $\mathrm{Na}^{+}, \mathrm{Ca}^{2+}$ and $\mathrm{Mg}^{2+}$ concentrations in $\mathrm{mmol} \mathrm{L}^{-1}$ using the following equation:

$$
S A R=\frac{\left[\mathrm{Na}^{+}\right]}{\sqrt{\left(\left[\mathrm{Ca}^{2+}\right]+\left[\mathrm{Mg}^{2+}\right]\right)}}
$$

Total organic $\mathrm{C}$ concentration in soils and residues was measured by the Walkey and Black method
(1934). Total $\mathrm{N}$ in soils and residues was measured by the Kjeldahl method (Bradstreet, 1965). Water extractable organic carbon (WEOC) in residues was determined by shaking $0.5 \mathrm{~g}$ ground residues in 30 $\mathrm{ml} \mathrm{RO}$ water for 1 hour after which the extract was filtered through a Whatman no. 42 filter. The organic $\mathrm{C}$ concentration in the extract was measured as described in Anderson and Ingram (1993) by digesting with $0.0667 \mathrm{M} \mathrm{K}_{2} \mathrm{Cr}_{2} \mathrm{O}_{7}$ and concentrated $\mathrm{H}_{2} \mathrm{SO}_{4}$ and titrating the remaining dichromate with $0.033 \mathrm{M}$ acidified $\left(\mathrm{NH}_{4}\right)_{2} \mathrm{Fe}\left(\mathrm{SO}_{4}\right)_{2} \cdot 6 \mathrm{H}_{2} \mathrm{O}$.

The composition of organic $\mathrm{C}$ compounds in the residues was determined by nuclear magnetic resonance (NMR) spectroscopy. The spectra were obtained on a Varian Unity 200 NMR spectrometer at a ${ }^{13} \mathrm{C}$ resonance frequency of $50.3 \mathrm{MHz}$. The residue samples were packed in a cylindrical zirconia rotor and spun at $5000 \pm 100 \mathrm{~Hz}$ in a Doty Scientific magic anglespinning (MAS) probe. The spectra were integrated into eight chemical shift regions for the following C-types: Alkyl (0 - 45 ppm), N-Alkyl/Methoxyl (45 - 60 ppm), O-Alkyl (60 - 95 ppm), Di-O-Alkyl (95 110 ppm), Aryl (110 - 145 ppm), O-Aryl (145 - 165 ppm), Amide/Carboxyl (165 - 190 ppm) and Ketone (190 - 215 ppm). For further details about the NMR analysis see Baumann et al. (2009).The percentage of biomolecules (carbohydrate, protein, lignin lipid and carbonyl) was calculated from ${ }^{13} \mathrm{C}$ NMR results using the molecular mixing model (Baldock et al., 2004). Klason lignin was determined as described in Hatfield and Fukushima (2005). Briefly, residues were washed with $80 \%$ ethanol and then digested in $12 \mathrm{M}$ sulfuric acid at $35^{\circ} \mathrm{C}$, followed by incubation in $2 \mathrm{M}$ sulfuric acid at $121^{\circ} \mathrm{C}$.

Soil microbial biomass carbon (MBC) concentration was determined by the fumigation extraction method (Vance et al., 1987). Soil samples were fumigated for 
$48 \mathrm{~h}$ with chloroform followed by shaking with $0.5 \mathrm{M}$ $\mathrm{K}_{2} \mathrm{SO}_{4}$ at $1: 5$ soil: solution ratio. The $\mathrm{C}$ concentration in the extract of fumigated and non-fumigated soils was determined by adding $0.0667 \mathrm{M} \mathrm{K}_{2} \mathrm{Cr}_{2} \mathrm{O}_{7}$ and concentrated $\mathrm{H}_{2} \mathrm{SO}_{4}$. The remaining $\mathrm{K}_{2} \mathrm{Cr}_{2} \mathrm{O}_{7}$ was titrated with $0.033 \mathrm{M}$ acidified $\left(\mathrm{NH}_{4}\right)_{2} \mathrm{Fe}\left(\mathrm{SO}_{4}\right)_{2} \cdot 6 \mathrm{H}_{2} \mathrm{O}$ (Anderson and Ingram 1993). The difference in $\mathrm{C}$ concentration between fumigated and non-fumigated soil was multiplied by 2.64 to calculate MBC concentration (Vance et al., 1987).

Soil respiration was determined by measuring the $\mathrm{CO}_{2}$ concentration in the headspace of each jar using a Servomex 1450 infra-red gas analyser as described in Setia et al. (2011a). After each measurement (t1), the jars were vented to refresh the headspace using a fan, and then resealed followed by determination of the $\mathrm{CO}_{2}$ concentration ( $\mathrm{t} 0$ ). The $\mathrm{CO}_{2}$ evolved during a given interval was calculated as the difference in $\mathrm{CO}_{2}$ concentration between $\mathrm{t} 1$ and $\mathrm{t} 0$. Due to the upper detection limit of the gas analyser $\left(2 \% \mathrm{CO}_{2}\right)$ and the decrease in respiration rate over time after residue addition, respiration was measured daily until day 14 and then every second day. Linear regression based on injection of known amounts of $\mathrm{CO}_{2}$ in the jars was used to define the relationship between $\mathrm{CO}_{2}$ concentration and detector reading. Cumulative respiration was calculated as the sum of respiration rates [in $\mathrm{mg}$ $\mathrm{CO}_{2}-\mathrm{C}$ (g soil and day $\left.)^{-1}\right]$.

\subsection{Statistical analysis}

There were three replicates per treatment in Experiment 1 and four replicates in Experiment 2, arranged in randomised block design. Data of cumulative respiration and $\mathrm{MBC}$ concentration was normally distributed and analysed by two-way ANOVA with salinity and residue treatments as fixed factors using Genstat $15^{\text {th }}$ edition (VSN Int. Ltd, UK).Tukey's multiple comparison test at $95 \%$ confident interval was used to determine significant differences among treatments. Regression was used to characterise the relationship between salinity and cumulative respiration in saline soils as percentage of the non-saline soil in Microsoft Excel 2010.

\section{Results}

Compared to sawdust, kikuyu shoots had a lower $\mathrm{C} / \mathrm{N}$ ratio, concentrations of organic $\mathrm{C}$ and water-extractable organic $\mathrm{C}$ and lower proportions of carbonyl-C, lipid $\mathrm{C}$ and lignin. Total $\mathrm{N}$ and protein concentration were higher in kikuyu than in sawdust (Table 2).

\subsection{Experiment 1}

In all treatments, cumulative respiration decreased with increasing EC (Figure 1). At all salinity levels, cumulative respiration was lowest with $100 \%$ sawdust and greatest with $100 \%$ kikuyu; it increased with increasing proportion of kikuyu in the mixes. The decrease in cumulative respiration from the non-saline soil to the soil with EC $1 \mathrm{dS} \mathrm{m}^{-1}$ was strongest with $100 \%$ sawdust. This decrease was smaller in all residue treatments with kikuyu.

There was a negative relationship between salinity and cumulative respiration in percentage of the nonsaline soil in all treatments $\left(r^{2}=0.8-0.9\right)$ (Figure 2). The sharpest decrease in cumulative respiration occurred from non-saline to $\mathrm{EC}_{1: 5} 1 \mathrm{dS} \mathrm{m}^{-1}$. The reduction in cumulative respiration with increasing salinity was greater with $100 \%$ sawdust than in the other treatments. 


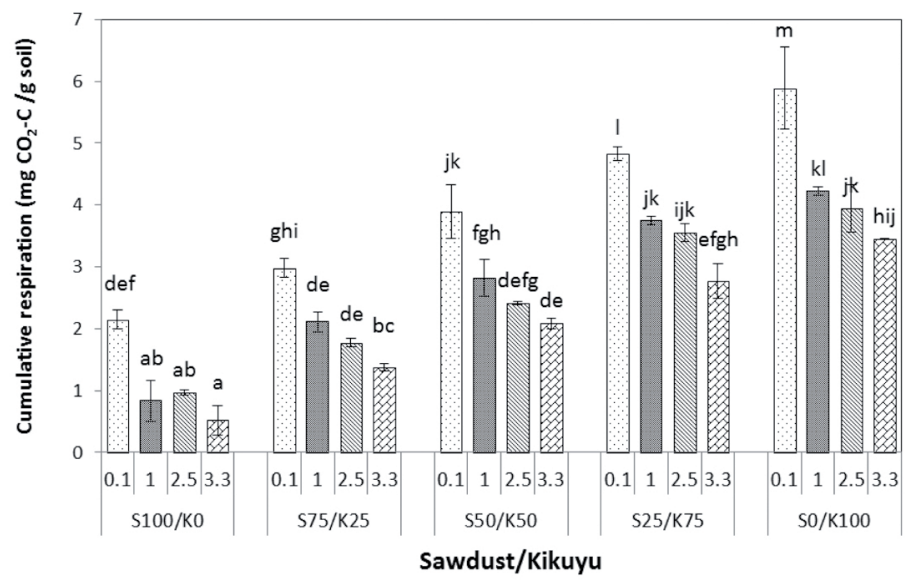

Figure 1. Cumulative respiration on day 16 in non-saline soil $\left(\mathrm{EC}_{1: 5} 0.1 \mathrm{dS} \mathrm{m}^{-1}\right)$ and saline soils $\left(\mathrm{EC}_{1: 5} 1,2.5\right.$ and 3.3 $\mathrm{dS} \mathrm{m}^{-1}$ ) amended with $2 \% \mathrm{w} / \mathrm{w}$ finely ground residues: sawdust or kikuyu alone (S100/K0 and S0/K100) or mixed at different ratios (weight percentage sawdust and kikuyu S75/K25, S50/K50, S25/K75)(n=3, vertical lines indicate standard deviation). Bars with different letters are significantly different $(\mathrm{P} \leq 0.05$, for the residue treatment $\mathrm{x}$ salinity interaction).

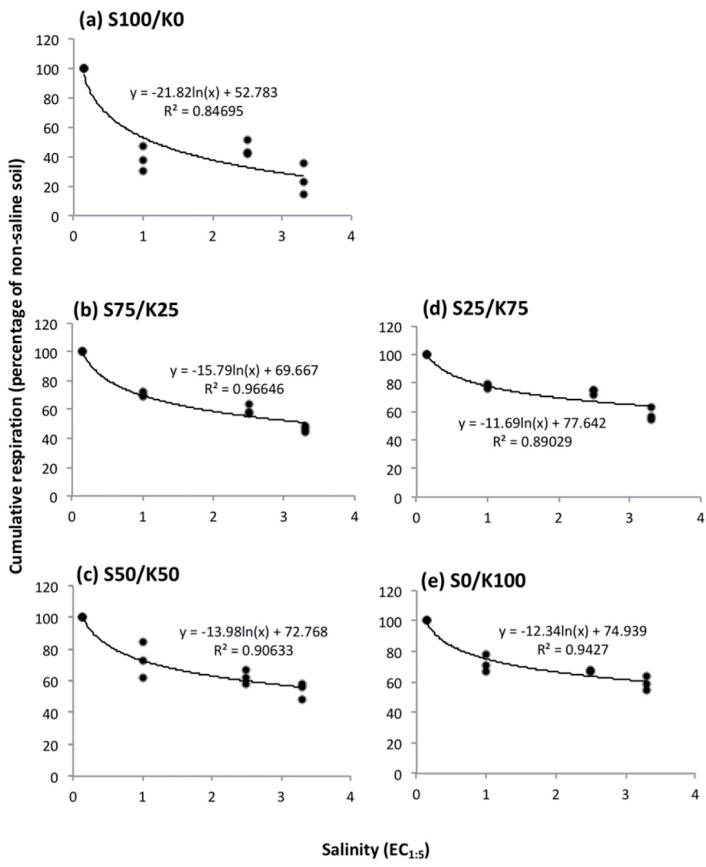

Figure 2. Relationship between cumulative respiration on day 15 in saline soils $\left(\mathrm{EC}_{1: 5} 0.1,1,2.5\right.$ and $\left.3.3 \mathrm{dS} \mathrm{m}^{-1}\right)$ as percentage of non-saline soil amended with $2 \% \mathrm{w} / \mathrm{w}$ sawdust, kikuyu and their mixtures: (a) S100/K0, (b) S75/ $\mathrm{K} 25$, (c) S50/K50, (d) S25/K75 (e) S0/K100 (n=3). 


\subsection{Experiment 2}

Cumulative respiration on day 42 was greater in soils amended only with kikuyu $(10 \mathrm{~K}, 5 \mathrm{~K}-2.5 \mathrm{~K}-2.5 \mathrm{~K})$ compared to the other treatments at all salinity levels (Figure 3). It was lowest in soils with sawdust only. In treatments where only one residue type was added (either kikuyu or sawdust), cumulative respiration was the same if residues were added once or three times. In treatments with $25 \%$ kikuyu $[7.5 \mathrm{~S}+2.5 \mathrm{~K}, 5 \mathrm{~S}-2.5 \mathrm{~S}-$
$2.5 \mathrm{~K}, 5 \mathrm{~S}-2.5 \mathrm{~K}-2.5 \mathrm{~S}$ and $(2.5 \mathrm{~S}+2.5 \mathrm{~K})-2.5 \mathrm{~S}-2.5 \mathrm{~S})]$, cumulative respiration was lowest in the treatment where kikuyu was added last (5S-2.5S-2.5K). Cumulative respiration was not significantly influenced by salinity in soils amended with kikuyu only (10K and $5 \mathrm{~K}-2.5 \mathrm{~K}-2.5 \mathrm{~K})$, but decreased from the non-saline soil to soil with EC $1 \mathrm{dS} \mathrm{m}^{-1}$ in treatments with sawdust alone or mixtures of sawdust and $25 \%$ kikuyu. Cumulative respiration did not differ between EC 1 and $2.5 \mathrm{dS} \mathrm{m}^{-1}$.

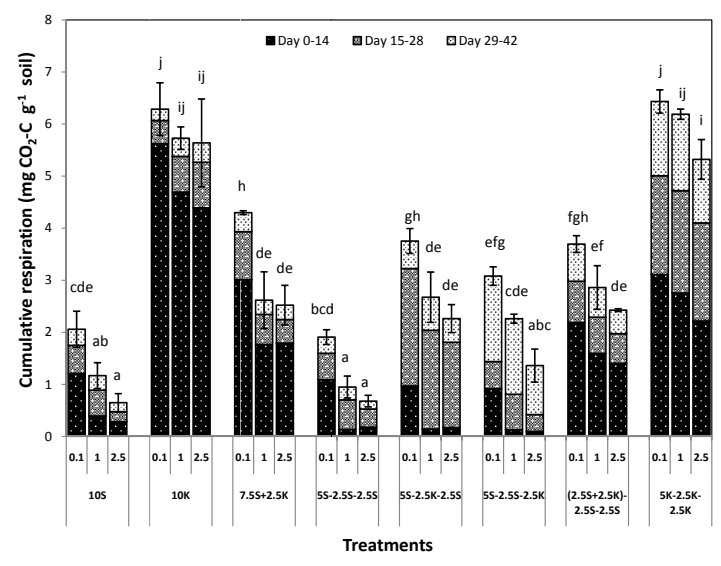

Figure 3. Cumulative respiration over 14 day periods: day 0-14, day 15-28 and day 29-42 in non-saline soil $\left(\mathrm{EC}_{1: 5} 0.1 \mathrm{dS} \mathrm{m}^{-1}\right)$ and saline soils $\left(\mathrm{EC}_{1: 5} 1.0\right.$ and $\left.2.5 \mathrm{dS} \mathrm{m}^{-1}\right)$ with mixed, single and multiple amendments of sawdust and kikuyu residues to achieve a total addition of $10 \mathrm{~g} \mathrm{C} \mathrm{kg}^{-1}$ soil ( $\mathrm{n}=4$, vertical lines indicate standard deviation). Different letters indicate significant differences $(\mathrm{P} \leq 0.05$, for the residue treatment $\mathrm{x}$ salinity interaction). For treatment structure, see Table 3.

In the two-week period after a total of $10 \mathrm{~g} \mathrm{C} \mathrm{kg}^{-1}$ had been added there was a strong negative logarithmic relationship between salinity and cumulative respiration in percentage of non-saline soil in soil with a single addition of sawdust (10S). (Figure 4, see Figures $\mathrm{S} 1$ and $\mathrm{S} 2$ for cumulative respiration after addition of 7.5 and $5 \mathrm{~g} \mathrm{~kg}^{-1}$ ). The reduction in cumulative respiration with increasing salinitywas smaller than with sawdust alone in soils amended with a singleaddition of $75 \%$ sawdust and $25 \%$ kikuyu $(7.5 \mathrm{~S}+2.5 \mathrm{~K})$ or kikuyu only (10K). In all other treatments, there was a linear relationship between salinity and percentage cumulative respiration with the greatest slope in soil with repeated addition of sawdust only (5S-2.5S-2.5S) and the smallest with repeated addition of kikuyu only $(5 \mathrm{~K}-2.5 \mathrm{~K}-2.5 \mathrm{~K})$. Among the treatments with multiple additions and $25 \%$ kikuyu, the slope was smallest in the 
treatment with kikuyu added on day 14 (5S-2.5K-2.5S) followed by the treatment where kikuyu was added on day 0 together with sawdust $[(2.5 \mathrm{~K}+2.5 \mathrm{~S})-2.5 \mathrm{~S}$ 2.5S].

The MBC concentration on day 42 was lower in soils with sawdust only compared to those with kikuyu only or mixes of sawdust and kikuyu (Figure
5). In the non-saline soil, the MBC concentration was greater with kikuyu only than in soils with mixtures of kikuyu and sawdust. Salinity influenced the MBC concentration only in some treatments. Compared to the non-saline soil, the MBC concentration was lower in soil with $2.5 \mathrm{dS} \mathrm{m}^{-1}$ only in treatments with a single residue addition (10S and 10K).
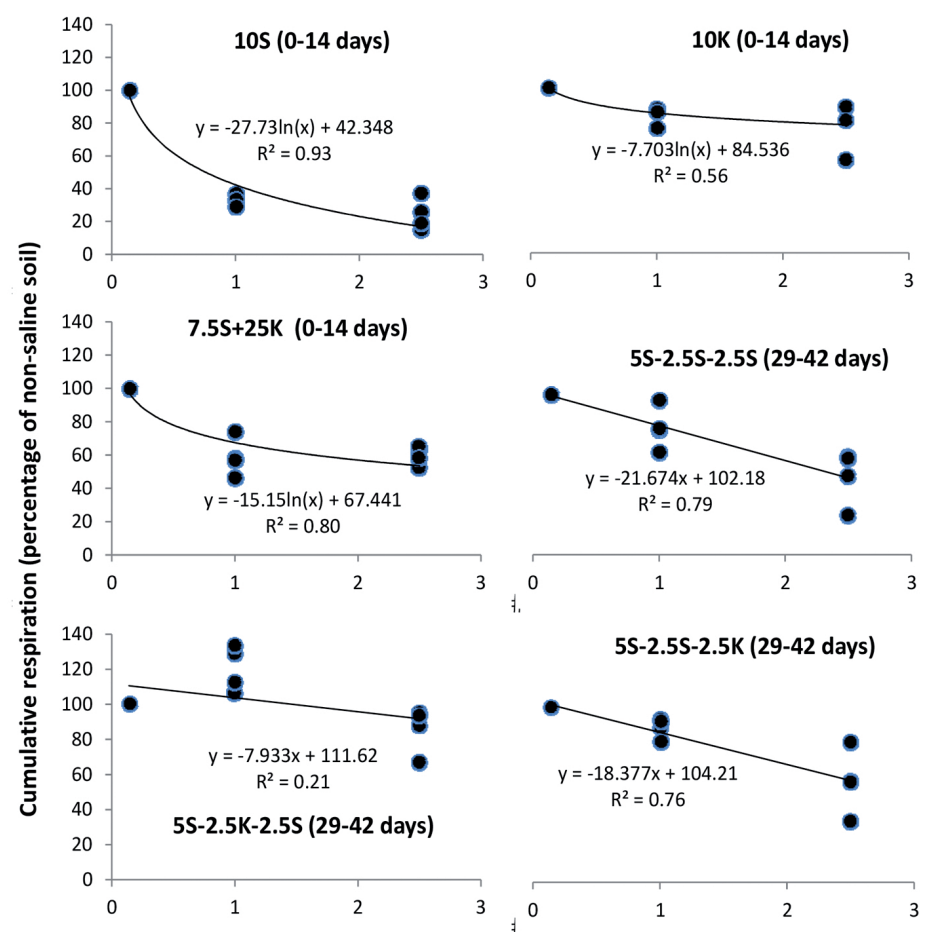

ł.

5S-2.5S-2.5K (29-42 days)
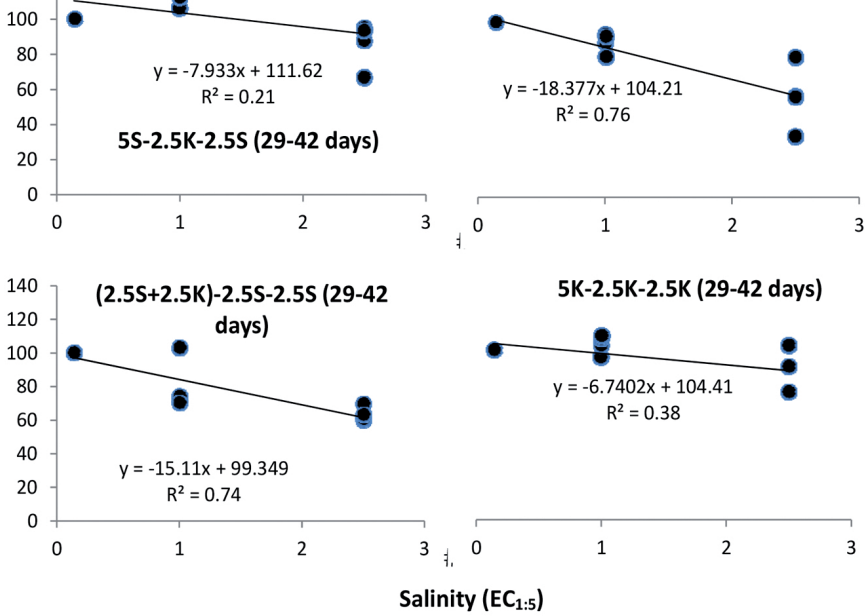

Figure 4. Relationship between cumulative respiration and salinity $\left(\mathrm{EC}_{1: 5} 0.1\right.$ and $\left.1,2.5 \mathrm{dS} \mathrm{m}^{-1}\right)$ as percentage of non-saline over 14 days after addition of a total of $10 \mathrm{~g} \mathrm{C} \mathrm{kg}^{-1}$ as sawdust, kikuyu and their mixtures with single and multiple additions $(n=4)$. Values in brackets indicate the period that was considered. For treatment structure, see Table 3. 


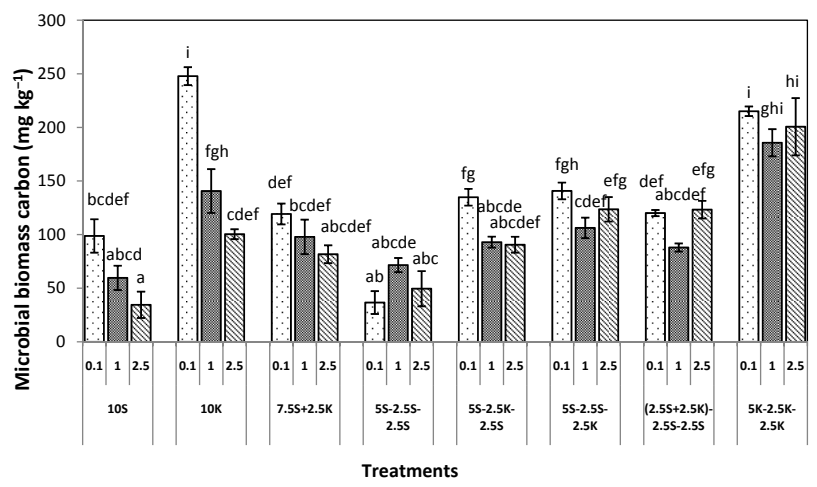

Figure 5. Microbial biomass $\mathrm{C}$ on day 42 in non-saline soil $\left(\mathrm{EC}_{1: 5} 0.1 \mathrm{dS} \mathrm{m} \mathrm{m}^{-1}\right)$ and saline soils $\left(\mathrm{EC}_{1: 5} 1.0\right.$ and 2.5 $\left.\mathrm{dS} \mathrm{m} \mathrm{m}^{-1}\right)$ with mixed, single and multiple amendments of sawdust and kikuyu residues at $10 \mathrm{~g} \mathrm{C} \mathrm{kg}^{-1}$ soil. $(\mathrm{n}=4 \pm$ vertical lines indicate standard error). Different letters indicate significant differences ( $\leq \leq 0.05$, for the residue treatment $\mathrm{x}$ salinity interaction). . For treatment structure, see Table 3.

\section{Discussion}

This study confirmed our earlier study (Hasbullah and Marschner, 2014) that the reduction in soil respiration with increasing salinity is smaller in soils amended with rapidly decomposable residues compared to slowly decomposable residues. The novel finding of this study is that even a small proportion of rapidly decomposable residues in a mixture with slowly decomposable residues is sufficient to reduce the negative effect of salinity on cumulative respiration compared to the slowly decomposable residue alone.

In Experiment 1, with a single addition, 25\% kikuyu in a mixture was sufficient to reduce the negative effect of salinity on cumulative respiration (Figure 2). However, there was little difference in ameliorative effect among mixtures with $25-75 \%$ rapidly decomposable residue and also compared torapidly decomposable residue alone. Therefore our first hypothesis that the negative effect of salinity on soil respiration will decrease with increasing proportion of rapidly decomposable residue in the mixture has to be declined. The alleviation of the negative effect of salinity by rapidly decomposable residues can be explained by several factors. Firstly, a greater amount of energy is available for the synthesis of osmolytes than with slowly decomposable residues because less energy has to be used for the synthesis of enzymes required for the breakdown of more complex compounds such as lignin. Accumulation of osmolytes in cells can counteract the strongly negative osmotic potential in saline soils (Keren, 2000). However, osmolyte synthesis requires large amounts of energy, 30-110 ATP compared with only 30 ATP for synthesising cell walls (Oren, 1999). Secondly, the kikuyu residues used here, and rapidly decomposable residues in general (Golueke, 1991), have a high $\mathrm{N}$ concentration (low C/N ratio) which increases $\mathrm{N}$ supply for microbes compared to slowly decomposable residues. Higher N supplyfacilitates osmolyte synthesis many of which are N-rich, for example, glycine betaine, proline and quaternary ammonium compounds (Warren, 2013). Further potential factors are that (i) rapidly decomposable residues 
induce a microbial community structure with a greater proportion of salinity-adapted microbes; (ii) the greater amount of energy and $\mathrm{N}$ provided may allow synthesis and release of microbial slimes which protect micro-colonies from water stress (Potts, 1994).

In Experiment 2, the effect of salinity on cumulative respiration did not differ greatly between single and multiple additions of either sawdust or kikuyu only (Figure 3). In case of sawdust, multiple additions apparently could not provide energy for adaptation to salinity, probably because even freshly added sawdust is poorly decomposable due to its high $\mathrm{C} / \mathrm{N}$ ratio and high lignin concentration (Silva et al., 2009). With kikuyu on the other hand, a single addition apparently provided sufficient rapidly decomposable compounds for salinity tolerance mechanisms.

In the treatments with mixtures of sawdust and kikuyu, the decrease in cumulative respiration from non-saline soil to EC $1 \mathrm{dS} \mathrm{m}^{-1}$ was greatest with a single addition $(7.5 \mathrm{~S}+2.5 \mathrm{~K}$ ) (Figure 4 ) and smallest in $5 \mathrm{~S}-2.5 \mathrm{~K}-2.5 \mathrm{~S}$. The smaller decrease in the latter treatment can be explained by the proportion of sawdust when kikuyu was added. In the two weeks following the first residue addition, $75 \%$ of added residues was sawdust in treatment $(7.5 \mathrm{~S}+2.5 \mathrm{~K})$ whereas it was only $50 \%$ in $5 \mathrm{~S}-2.5 \mathrm{~K}-2.5 \mathrm{~S}$. Therefore a greater proportion of microbes in the soil would have kikuyu in their vicinity and could decompose it in the latter. This early provision of rapidly decomposable residue to a greater proportion of soil microbes was sufficient to reduce the negative impact of salinity effect throughout the 42 days although later only sawdust was added and therefore most soil microbes were in the vicinity of slowly decomposable residues. This suggests that the proportion of total residue in the soil as slowly decomposable residue when rapidly decomposable residue is added is important for the response of respiration to salinity. This confirms the second hypothesis, that with multiple residue additions, the negative impact of salinity on cumulative respiration will increase with proportion of slowly decomposable residue in the soil at the time of addition of rapidly decomposable residue.

The greater decomposability of kikuyu compared to sawdust also lead to a greater MBC concentration in soil amended with kikuyu (Figure 5). However, the differences in MBC concentration between kikuyu and sawdust were smaller than in cumulative respiration. The MBC concentration was about two-fold higher with kikuyu compared to sawdust whereas cumulative respiration was five to six times higher (Figure 4). The smaller difference in MBC between treatments can be explained by the fact that MBC was determined only once at the end of the experiment whereas cumulative respiration was integrated over the entire experiment. By then a proportion of the microbial biomass may have already died because of depletion of readily available organic $\mathrm{C}$ This can also explain the lack of impact of salinity on MBC concentration.

\section{Conclusion}

The first experiment showed that with a single addition, $25 \%$ of rapidly decomposable residue in the mix was sufficient to reduce the negative effect of salinity on respiration compared slowly decomposable residue alone. This could reduce costs of amelioration of saline soils because slowly decomposable residues are often cheaper and available in greater amounts than rapidly decomposable residues. However, when residues are added several times, the ameliorative effect of rapidly decomposable residue on soil respiration can be maximised by adding them early, that is, when only small amounts of slowly decomposable residue are present in the soil. Longer-term field studies are required to investigate how often residues or mixtures would have to be applied for a sustained ameliorative effect. 


\section{Acknowledgements}

We thank the University of Adelaide for providing a postgraduate scholarship to H. Hasbullah.

\section{References}

Anderson, J.M., Ingram, J.S.I. 1993. Tropical soil biology and fertility: a handbook of methods. C.A.B. International, Wallingford, $171 \mathrm{p}$.

Ashworth, J., Keyes, D., Kirk, R., Lessard, R. 2001. Standard procedure in the hydrometer method for particle size analysis. Commun. Soil Sci. Plant Anal. 32, 633-642.

Baldock, J.A., Masiello, C., Gelinas, Y., Hedges, J. 2004. Cycling and composition of organic matter in terrestrial and marine ecosystems. Mar. Chem. 92, 39-64.

Baumann, K., Marschner, P., Smernik, R.J., Baldock, J.A. 2009. Residue chemistry and microbial community structure during decomposition of eucalypt, wheat and vetch residues. Soil Biol. Biochem. 41, 1966-1975.

Bradstreet, R.B. 1965. The Kjeldahl method for organic nitrogen. Academic Press, New York, 239 p.

Golueke, C. 1991. Principles of composting, The staff of biocycle journal of waste recycling. The Art of Science of Composting. The JG Press Inc, Pennsylvania, USA, pp. 14-27.

Hagemann, M. 2011. Molecular biology of cyanobacterial salt acclimation. Fems Microbiol. Rev. 35, 87-123.

Haines, W.B. 1930. Studies in the physical properties of soil. V. The hysteresis effect in capillary properties, and the modes of moisture distribution associated therewith. J. Agric. Sci. 20, 97-116.

Hasbullah, H., Marschner, P. 2014. Residue properties influence the impact of salinity on soil respiration. Biol. Fertil. Soils, 1-13.
Hatfield, R., Fukushima, R.S. 2005. Can lignin be accurately measured?. Crop Sci. 45, 832-839.

Keeney, D.R., Nelson, D.W. 1982. Nitrogen-Inorganic Forms. In: Page, A.L. (Ed.), Methods of soil analysis. Part 2. Chemical and microbiological properties. Agronomy Monograph, Wisconsin, pp. 643-698.

Keren, R. 2000. Salinity. In: Sumner, M.E. (Ed.), Handbook of soil science. CRC press, pp. 3-25.

Lambers, H. 2003. Introduction, dryland salinity: a key environmental issue in southern Australia. Plant Soil. 257, 5-7.

Marschner, P. 2012. Marschner's Mineral Nutrition of Higher Plants. Academic press, Sydney, 455 p.

Oren, A. 1999. Bioenergetic aspects of halophilism. Microbiology and Molecular Biology Reviews. 63, 334-348.

Pessarakli, M., Szabolcs, I. 1999. Soil salinity and sodicity as particular plant/crop stress factors. Handbook of plant and crop stress. Marcel Dekker, New York, 1-15.

Potts, M. 1994. Desiccation tolerance of prokaryotes. Microbiol. rev. 58, 755.

Rayment, G., Higginson, F.R. 1992. Australian laboratory handbook of soil and water chemical methods. Inkata Press Pty Ltd, Melbourne, 330 p.

Rietz, D., Haynes, R. 2003. Effects of irrigation-induced salinity and sodicity on soil microbial activity. Soil Biol. Biochem. 35, 845-854.

Saxton, K., Rawls, W.J., Romberger, J., Papendick, R. 1986. Estimating generalized soil-water characteristics from texture. Soil Sci. Soc. Am. J. 50, 1031-1036.

Setia, R., Marschner, P., Baldock, J., Chittleborough, D., Verma, V. 2011a. Relationships between carbon dioxide emission and soil properties in saltaffected landscapes. Soil Biol. Biochem. 43, 667674. 
Setia, R., Smith, P., Marschner, P., Baldock, J., Chittleborough, D.J., Smith, J. 2011b. Introducing a decomposition rate modifier in the Rothamsted carbon model to predict soil organic carbon stocks in saline soils. Environ. Sci. Technol. 45, 6396-6403

Shaw, R., Hughes, K., Thorburn, P., Dowling, A. 1987. Principles of landscape, soil and water salinity-processes and management options. Part A. Landscape, Soil and Water Salinity. Proceedings of the Brisbane regional salinity workshop. Brisbane. Australia.

Silva, M.E., Lemos, L.T., Cunha-Queda, A.C., Nunes, O.C. 2009. Co-composting of poultry manure with low quantities of carbon-rich materials. Waste Manage. Res. 27, 119-128.

Sumner, M.E., Naidu, R. 1998. Processes involved in sodic behavior. In: Rengasamy, P., Sumner, M. (Eds.), Sodic soils - distribution, properties, management and environmental consequences. Oxford University Press, New York, pp. 35-50.

Vance, E., Brookes, P., Jenkinson, D. 1987. An extraction method for measuring soil microbial biomass C. Soil Biol. Biochem. 19, 703-707.

Walkley, A., Black, I.A. 1934. An examination of the Degtjareff method for determining soil organic matter, and a proposed modification of the chromic acid titration method. Soil Sci. 37, 29-38.
Warren, C.R. 2013. High diversity of small organic $\mathrm{N}$ observed in soil water. Soil Biol. Biochem. 57, 444-450.

Yan, N., Marschner, P. 2012. Response of microbial activity and biomass to increasing salinity depends on the final salinity, not the original salinity. Soil Biol. Biochem. 53, 50-55.

Zarcinas, B.A., McLaughlin, M.J., Smart, M.K. 1996. The effect of acid digestion technique on the performance of nebulization systems used in inducWalkley, A., Black, I.A. 1934. An examination of the Degtjareff method for determining soil organic matter, and a proposed modification of the chromic acid titration method. Soil Sci. 37, 29-38.

\section{Web reference}

Meat and Livestock Australia, Available from: $<$ http://weather.mla.com.au/climate-history/sa/ monarto $>[12$ February 2015] 